\title{
Control of follicular development and ovulation rate in pigs
}

\author{
Nancy M. Cox \\ Department of Animal and Dairy Sciences, Mississippi State University, Mississippi State, \\ MS 39762, USA
}

\begin{abstract}
There is considerable evidence that nutritional and metabolic control of follicular growth is mediated by metabolic hormones and growth factors, particularly with processes mediated by insulin-like growth factor I (IGF-I) and its binding proteins (IGFBPs). From knowledge that hormones and growth factors which can be affected by diet also positively affect ovarian function, the concept has emerged that metabolic modifiers of gonadotrophin action, rather than gonadotrophins themselves, could affect follicle development. While ovulation rate can be enhanced under certain conditions in cyclic gilts, assessing influences of metabolic modifiers on the post-lactational sow is confounded by variability in the return to oestrus after weaning. In a series of studies involving insulin administration between weaning and oestrus, successive experiments produced different results, but several measures of reproductive performance were enhanced. Administration of somatotrophin (ST) has also been shown to increase follicular development in both gilts and sows. Both insulin and ST increase IGF-I production by pig ovarian follicles, and insulin is more effective than IGF-I in reducing atresia and increasing progesterone in cultured pig follicles. Whether increases in litter size are achieved after an increase in ovulation rate involves many factors, including the quality of ova and whether the increase in ovulation rate exceeds the uterine capacity to maintain pregnancy. Given the variation in genetics and management practices, development of treatments to enhance follicle quality leading to maximal litter size is challenging.
\end{abstract}

\section{Introduction}

Although it has long been known that exogenous gonadotrophins increase follicular development and ovulation rate, the number of ovulations is variable and may have negative effects on embryo survival. Nutritional and hormonal manipulation may enhance follicular development, both by enhancing gonadotrophin secretion directly and by enhancing the ovarian response in the face of unvarying gonadotrophin concentrations. Given the knowledge that hormones and growth factors that can be affected by diet also positively affect ovarian function, the concept that metabolic modifiers, rather than gonadotrophins themselves, could be applied to affect follicle development has emerged. This review will concentrate mainly on metabolic interfaces between nutrition and reproduction rather than nutritional manipulations themselves. Emphasis will be on follicle development rather than embryo survival; effects of metabolic manipulations on embryo survival are discussed by Foxcroft (this volume).

When consideration is given to increasing ovulation rate, there are practical limitations. First, while ovulation rate and litter size are positively correlated up to approximately 18 ovulations, ovulations beyond that point result in little or no increases in litter size (Wu et al., 1987). In mature sows and gilts on full feed, ovulation rates are usually maximal, and manipulation of follicular 
development to increase ovulation rate will not be useful. However, in animals with lower ovulation rates, such as gilts on the first or second oestrous cycle and primiparous sows, augmentation of ovulation rate may be useful.

\section{Current Concepts of Follicle Growth, Atresia and Ovulation Rate}

It is well established that the ovulatory population of follicles increases growth between about day 14 and day 16 of the oestrous cycle. Granulosa and theca cell proliferation decreases between day 15 and oestrus, which indicates differentiation (Fricke et al., 1996). Between day 16 and oestrus, there is a loss of $40-50 \%$ of the medium-sized follicles due partly to growth of follicles to the next size category but mostly to atresia (Guthrie et al., 1995a). Exposure to FSH during the last stages of granulosa cell mitosis appears to be required so that some follicles can escape atresia (Hsueh et al., 1994). In pigs, FSH patterns were temporally correlated with atresia, decreasing at the time atresia increased (Guthrie et al., 1993). Apoptotic cell death in the ovary has been characterized by several biochemical markers including decreased DNA turnover, decreased oestrogen production, increased progesterone production, a decrease in the number of gonadotrophin receptors and increased production of IGF-binding protein (Hsueh et al., 1994). Thus follicular atresia is considered to be a result of a balance between survival and atretogenic factors. Follicle survival factors include, but are not limited to, epidermal growth factor, nerve growth factor, insulin-like growth factor I (IGF-I), gonadotrophins, activin and oestrogens, while atretogenic factors include testosterone, GnRH and interleukins (Hsueh et al., 1994).

In the pig ovary as in the ovaries of other species, apoptotic cell death is the mechanism by which follicular atresia occurs (Guthrie et al., 1995a). Guthrie et al. (1995a) demonstrated that apoptosis could be assessed in gilts by flow cytometric analysis and that these measures were correlated highly with oestradiol production and with morphological assessment of atresia. Atresia was highest in medium-sized $(3-6 \mathrm{~mm}$ ) follicles $(87 \%)$ on day 5 after withdrawal of Altrenogest (Guthrie et al., 1994), which corresponds to the late stages of preovulatory maturation before the LH surge. In contrast, the percentage of atretic granulosa cells was $17 \%$ in medium-sized follicles on days 1 and 3 after Altrenogest withdrawal, which corresponds to earlier stages of preovulatory follicular development (Guthrie et al., 1994). These researchers also demonstrated that during the early luteal phase, there is a wave of follicular growth followed by atresia (Guthrie et al., 1995a). In contrast, during follicular growth in the latter part of the luteal phase between day 7 and day 15, there was no change in the percentage of atretic follicles, indicating that follicular growth in pigs may not be characterized by repeated waves of follicular development (Guthrie and Cooper, 1996). The most severely affected enzyme was p450 aromatase, which was undetectable in atretic follicles (Garrett and Guthrie, 1996). In contrast, 3 $\beta$-hydroxysteroid dehydrogenase and $\mathrm{P} 450_{\mathrm{c} 17}$ lyase were not affected by atresia, which is in agreement with other work which demonstrates that progesterone production continues in atretic follicles (Guthrie et al., 1994). Figure 1 illustrates identification of Ki67, a nuclear antigen associated with cell proliferation, aromatase and detection of apoptosis in atretic and nonatretic follicles. Since oestrogen is a follicle survival factor that reduces atresia (Hsueh et al., 1994), aromatase expression may be critical for survival of follicles.

Techniques for enhancing follicular development include methods that may either influence negative feedback relationships with gonadotrophins or intrafollicular control mechanisms. Immunization against inhibin (King et al., 1993) and androstenedione (McKinnie et al., 1988) increase ovulation rate but their effects on litter size have not been evaluated. However, immunization against the $\alpha$-subunit of inhibin prevented the compensatory increase in corpora lutea following unilateral ovariectomy, suggesting a local effect of inhibin (King et al., 1995). There is increasing evidence for intraovarian paracrine regulation by inhibin and related peptides, and further refinement of these relationships may result in more predictable control of ovulatory processes (Findlay et al., 1996). Manipulation of the steroid environment may also influence ovulation rate. When testosterone was administered between day 13 and oestrus, ovulation rate and the number of recovered blastocysts were increased (Cardenas and Pope, 1997). Part of the mechanism may be provision of a substrate for oestradiol production, but the mechanism is not known. 

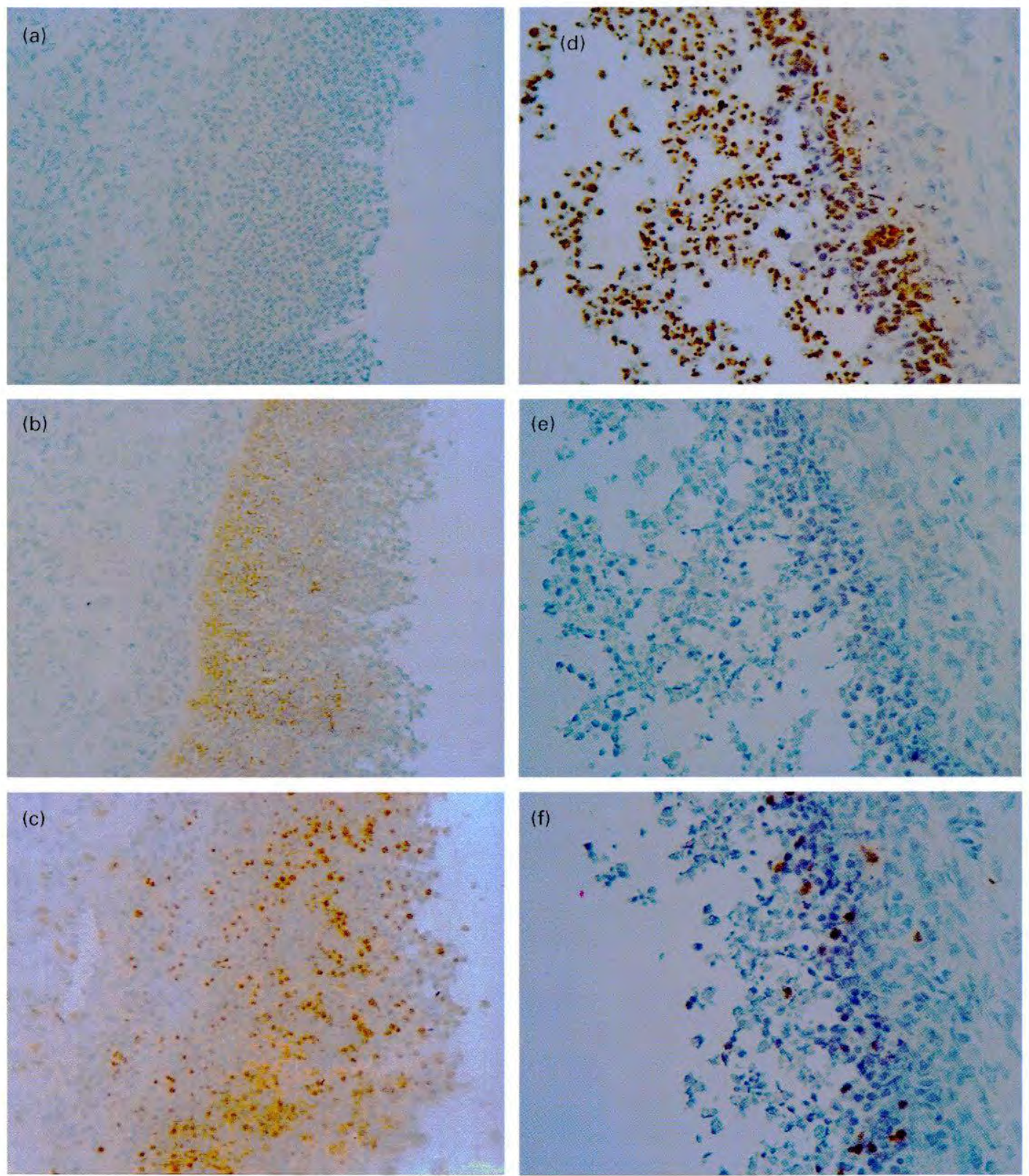

Fig. 1. Photomicrographs of sections from ovarian follicles from non-atretic $(a-c)$ and atretic (d-f) follicles. Sections (a) and (d) are 3' end-labelled to detect apoptosis; sections (b) and (e) are immunostained for aromatase, and sections (c) and (f) are immunostained for cell proliferation-associated antigen, Ki-67 (W. Garrett and D. Guthrie, unpublished).

\section{Metabolic Influences on Components of the Hypothalamo-Hypophyseal-Ovarian Axis}

Although positive associations between level of feed intake and ovulation rate or litter size are well established (reviewed by Einarsson and Rojkittikhun, 1993; Cosgrove and Foxcroft, 1996), the mechanisms by which increased nutritional status affects ovarian function have not been 
established. In gilts, the principal effect of feed restriction is to compromise the GnRH pulse generator, and realimentation or glucose infusion restores LH pulses (Booth, 1990), while insulin restores follicular growth (Britt et al., 1988). Charlton et al. (1993) observed lowered ovarian IGF-I mRNA with restricted feeding, but refeeding did not increase IGF-I mRNA. In feed-restricted lactating sows, glucose infusion did not affect pulsatile LH secretion (Tokach et al., 1992b). These results suggest that metabolic state can affect the $\mathrm{LH}$ response to a stimulus such as glucose.

When extra feed was given to cyclic gilts, increases in ovulation rate were accompanied by increases in LH pulse frequency and FSH, as well as insulin (Cox et al., 1987; Flowers et al., 1989). However, in the studies of Cox et al. (1987), increases in ovulation rate stimulated by dietary energy or exogenous insulin were not necessarily accompanied by increased LH. In ovariectomized gilts with insulin depleted by diabetes mellitus and without insulin therapy for 4 days, pulsatile LH secretion was not altered (Angell et al., 1996). When ovary-intact diabetic gilts were depleted of insulin on day 12 of the oestrous cycle, LH pulse frequency increased between day 12 and day 18 , and LH increased again at the time at which normal gilts had preovulatory LH surges (Cox et al., 1994). In spite of the absence of adverse effects on gonadotrophins, follicle growth decreased and atresia increased (Meurer et al., 1991; Cox et al., 1994). Taken together, these results suggest that the effect of metabolic modifiers of reproduction on ovarian function does not require changes in gonadotrophins.

In considering the applicability of using metabolic modifiers to enhance ovulation rate in gilts, it must be considered that maximal feed intake will produce maximal ovulation rates (Beltranena et al., 1991). In contrast, sows, in which weaning triggers preovulatory development, are more vulnerable to the metabolic influences of the previous lactation. Despite the increased LH pulsing that is stimulated by weaning, there is considerable variability in follicular development and steroid secretion (Foxcroft et al., 1987). The primiparous sow is particularly susceptible to delayed oestrus after weaning or smaller litter sizes, suggesting that when metabolic factors interface with enhanced gonadotrophin secretion at weaning, follicle development can be affected. In support of this concept, Clowes et al. (1994) observed greater litter sizes (12.8 versus 10.4) and increased insulin concentrations when remating was delayed until the second post-weaning oestrus. Understanding of metabolic influences in sows is further complicated by a non-linear relationship between interval to oestrus and litter size and perhaps ovulation rate (Vesseur et al., 1994). Thus metabolic manipulations that affect the interval from weaning to oestrus could alter litter size.

Research assessing influences of nutritional manipulations on ovarian function in sows has demonstrated that ovarian function after weaning can be affected by metabolic state during lactation. Tokach et al. (1992a) and Koketsu et al. (1996) demonstrated that concentrations of insulin and glucose and the number of LH pulses during lactation were greater in sows with normal intervals to oestrus (Fig. 2). Zak et al. (1997) observed that restricting feed during weeks 1-3 or week 4 of lactation decreased ovulation rate and increased the weaning to oestrus interval in primiparous sows. Circulating insulin and IGF-I were reduced during feed restriction, and embryo survival was decreased only in sows receiving less feed during the last week of lactation. Feeding starch as an energy source during lactation may also facilitate LH production and ovarian function after weaning (Kemp et al., 1995). Thus dietary manipulation clearly can affect ovarian function after weaning, perhaps by affecting follicles during the lactation phase or before, as well as embryo survival.

\section{Role of Metabolic Hormones on Ovarian Function}

The insulin-like growth factor I system

A preponderance of evidence confirms positive associations between IGF-I and follicle function in swine, although most of these studies were performed in vitro (reviewed by Hammond et al., 1993; Spicer and Echternkamp, 1995). Although, as indicated above, nutrition modulates systemic concentrations of IGF-I, there is local control of IGF-I as well as other intraovarian compounds, and this explains the marked heterogeneity of follicles in the face of a similar endocrine milieu (Tonetta 

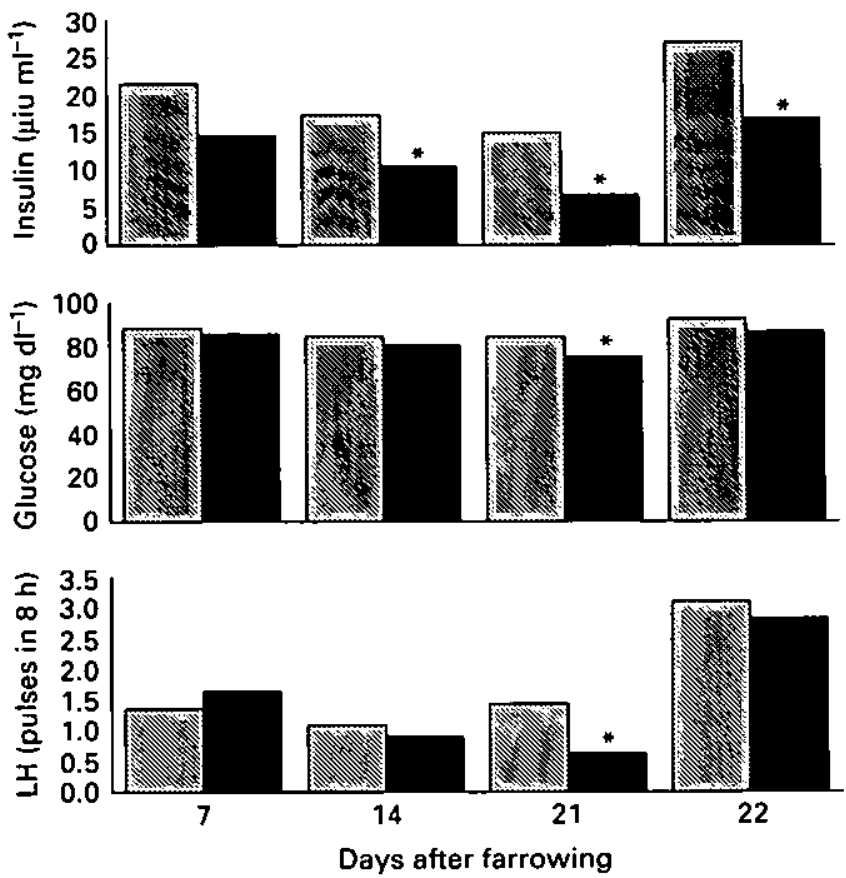

Fig. 2. Patterns of insulin, glucose and LH in sows categorized on the basis of days to oestrus (国 in oestrus $<7$ days after weaning $n=23$; and $\square$, in oestrus $>7$ days after weaning, $n=11$ ). Day 22 represents the first day after weaning. In sows with delayed oestrus, serum insulin was lower on days 14, 21 and 22, and glucose and number of LH pulses were lower on day $21(P<0.05)$. SEMs ranged from 1.43 to $2.67,1.35$ to 2.88 , and 0.16 to 0.35 for insulin, glucose and LH pulses, respectively. Redrawn from Koketsu et al. (1996).

and diZerega, 1990). Synthesis of IGF-I by granulosa cells from pigs has been demonstrated, and production of IGF-I is increased by gonadotrophins and growth hormone in vitro (Hammond et al., 1993). Messenger RNA for both IGF-I and -II increased with increasing size of follicles (Yuan et al., 1996). In contrast, Zhou et al. (1996) observed that IGF-I and IGF-I receptor mRNA were concentrated in healthy follicles, whereas mRNA encoding IGF-II was found in all follicles regardless of the degree of atresia. This finding suggests a functional paracrine role for IGF-I but does not allow conclusions for IGF-I, although IGF-II affects steroidogenesis (Spicer and Echternkamp, 1995). The IGF-binding proteins modulate effects of IGF-I systemically as well as in the ovary and are in general considered to inhibit follicular development (Hammond et al., 1993).

Recent evidence indicates that IGFBPs, as well as IGF-I, are related to follicular function in swine. Expression of mRNA encoding IGF-I increased as follicles increased in size during the oestrous cycle, whereas expression of the IGFBP-2 gene was greater in smaller follicles, and IGFBP-3 was not detected in follicles using Northern blot analysis (Hammond et al., 1993). Yuan et al. (1996) demonstrated that most IGFBP-2 gene expression was in the theca interna cells and was lower in large antral than in small antral follicles in that cell type, but decreased less markedly in granulosa cells. Concentrations of IGFBP-2 in follicular fluid were also inversely related to follicular diameter or oestradiol production (Howard and Ford, 1992) and were positively related to atresia in the early luteal phase as well as during preovulatory maturation (Guthrie et al., 1995b). Despite the association with atresia, mRNA encoding IGFBP-2 was detected in healthy, preovulatory follicles (Zhou et al., 
1996). In contrast, IGFBP-3 was not associated with atresia (Guthrie et al., 1995b; Edwards et al., 1996), although addition of IGFBP-3 to cultured rat follicles prevented IGF-I from acting as a survival factor (Chun et al., 1994). Messenger RNA for IGFBP-3 was not detected in the ovary at the follicular phase (Zhou et al., 1996), but recent evidence from our laboratory using a sensitive ribonuclease protection assay in individual follicles suggests that mRNA for IGFBP-3 is present in the walls of preovulatory follicles (Cox and Qiu, 1995). Associations between atresia and IGFBP-4 and -5 have been reported, but these IGFBPs are present at low concentrations in the follicular fluid of pigs (Guthrie $e$ t al., 1995b). However, Zhou et al. (1996) observed that mRNA for IGFBP-4 was associated with the presence of LH receptor gene expression in granulosa cells, indicating a role that is more complex than mediation of atresia. In addition to alterations in gene expression, IGFBPs in follicular fluid may be altered by posttranslational processing, including proteolysis. Recent evidence in swine indicates that proteolytic activity for IGFBP $-2,-4$ and -5 increased during follicular growth and was decreased during atresia (Besnard et al., 1997). Thus factors that influence activity of proteases for IGFBPs represent another level of control of follicle function.

Insulin-like growth factor $I$ is a strong survival factor for rat follicles, attenuating apoptosis in a similar way to gonadotrophins (Chun et al., 1994). Insulin also acted as a survival factor in that study, but was less potent than IGF-I. Growth hormone, which increased IGF-I, nevertheless did not reduce atresia in the rat early antral or preovulatory follicle (Chun et al., 1994, 1996). In contrast to the rat model, we have obtained evidence that insulin is more potent in reducing apoptosis and increasing progesterone than IGF-I in pig follicles (Purvis et al., 1997). The model we developed was aimed at studying the population of medium follicles (4 mm diameter) representative of days 16-18 of the oestrous cycle. It was considered that this population, although non-atretic when obtained, has a high potential for atresia. We have previously determined that follicles cultured in the presence of FSH (100 $\left.\mathrm{ng} \mathrm{ml}^{-1}\right)$ produce oestradiol linearly over time in culture (Edwards et al., 1996). Addition of insulin to FSH reduced apoptosis, whereas IGF-I had no effect (Fig. 3). Insulin (50 $\mathrm{ng} \mathrm{m}^{-1}$ ) also increased progesterone concentrations, but $5000 \mathrm{ng}$ IGF-I ml${ }^{-1}$ did not affect progesterone. The mechanism of insulin action does not appear to involve mediation by IGF-I, because intrafollicular IGF-I concentrations were higher in insulin-treated follicles but were similar to those produced by addition of IGF-I. Interestingly, insulin increased IGFBP-2 in medium after culture for $23 \mathrm{~h}$, but not in follicular fluid, whereas IGF-I did not alter IGFBP-2 compared with controls. In cultures of pig preantral follicles that already contained $1 \%$ insulin in the medium, IGF-I enhanced growth although the increase was less than with FSH or epidermal growth factor (Flowers and Turner, 1996). There have been few attempts to administer IGF-I in vivo to affect follicular function in pigs.

Both insulin and ST increase IGF-I production systemically and in the ovarian follicle, and both affect IGFBP production, although each hormone responds to circulating glucose in opposite ways (Spicer and Echternkamp, 1995). In our laboratory the combined influences of pST and insulin on follicular development were examined by inducing diabetes mellitus in gilts that had been immunized against growth hormone-releasing hormone (provided by Jeffrey D. Armstrong of North Carolina State University) (Howell et al., 1993). The two treatments were compared with control animals in a $2 \times 2$ factorial arrangement. Immunoneutralization of GHRH lowered follicular IGF-I concentrations from 245 to $113 \mathrm{ng} \mathrm{ml}^{-1}$ but did not affect oestradiol concentrations on day 18 of the oestrous cycle, after half the diabetic gilts were without insulin therapy from day 12 (Fig. 4). In contrast, diabetes mellitus significantly lowered both IGF-I (104 versus $254 \mathrm{ng} \mathrm{ml}^{-1}$ ) and oestradiol (71 versus $301 \mathrm{ng} \mathrm{ml}^{-1}$ ), as well as the number of follicles greater than $2 \mathrm{~mm}$ (31.5 versus 58.3). Another unique effect of diabetes mellitus, but not GHRH immunoneutralization, was that IGFBP-2 was increased in follicles to $186 \%$ of control values. However, follicular IGFBP-3 was reduced to $50 \%$ of control values as a result of GHRH immunoneutralization. Therefore, although the functional absence of either ST or insulin decreased IGF-I in follicular fluid, reduction in IGFBP-3 activity may have ameliorated negative effects of lowered IGF-I. In contrast, the combined influence of increased IGFBP-2 and decreased IGF-I in follicles of diabetic gilts may account for decreased follicular function. Interactions among systemic insulin, ST, IGFBPs and IGF-I as well as intrafollicular interactions beween the last two factors may function to control normal follicular responses to alterations in metabolism. 


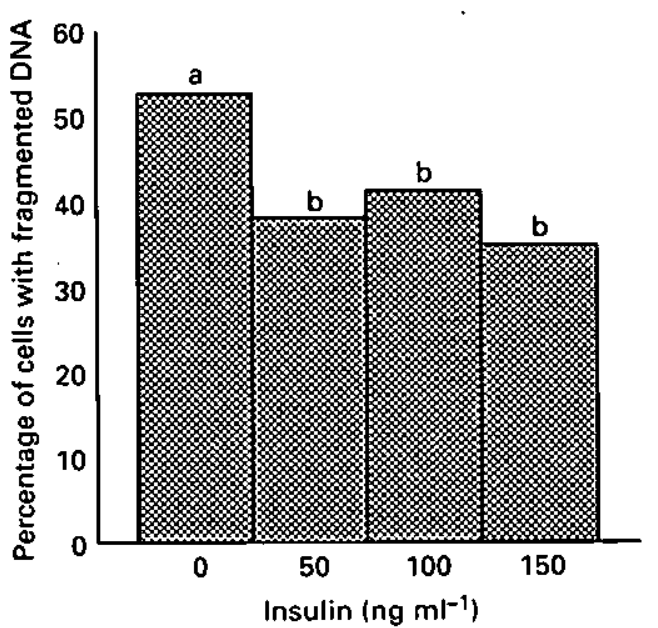

Fig. 3. Percentage of granulosa cells with fragmented DNA identified using cell flow cytometry in $4 \mathrm{~mm}$ follicles (six per treatment) from luteal phase ovaries cultured for $23 \mathrm{~h}$ with $100 \mathrm{ng} \mathrm{ml}^{-1}$ porcine $\mathrm{FSH}$ supplemented with insulin. All doses of insulin decreased apoptosis $(P<0.05)$. The SEM was $5.3 \%$. Redrawn from Purvis et al. (1997).

\section{Insulin}

Follicle development in gilts. We have previously observed that administration of insulin to cyclic gilts during the first pubertal oestrous cycle increased ovulation rate (Cox et al., 1987) and reduced follicle atresia (Matamoros et al., 1990) in gilts at the second postpubertal oestrus. In prepuberal, eCG-treated gilts, we observed an increase of IGF-I in medium-sized follicles of gilts given insulin (Matamoros et al., 1991). In contrast, when insulin was administered to gilts during days 13-17 of the fifth postpubertal oestrous cycle, IGF-I and oestradiol concentrations were decreased and atresia was not affected (Hughey et al., 1993). This result suggests that effects of insulin may be related to age, maturity and (or) related metabolic changes.

We demonstrated that normal ovarian function could be maintained in streptozotocin-induced diabetic pigs given daily insulin injections from 35 days of age until initiation of oestrous cycles, but that withdrawal of insulin therapy reduced follicle diameter and oestradiol production and increased atresia (Meurer et al., 1991; Cox et al., 1994; Edwards et al., 1996). Upon withdrawal of insulin replacement therapy, the incidence of follicular atresia increased within 2 days. Gene expression for IGF-I in follicle walls, as well as IGF-I in follicular fluid, decreased rapidly upon withdrawal of insulin, and IGFBP-2 in follicular fluid increased (Cox and Qiu, 1995; Fig. 5). Neither mRNA encoding IGFBP-3 nor IGFBP-3 in follicular fluid (not shown) was affected by diabetes. Both lowered IGF-I and increased IGFBP-2 probably contributed to the increased atresia and lowered oestradiol.

There is evidence that $4-6 \mathrm{~mm}$ follicles are particularly affected by insulin. First, it was the medium-sized follicle population that was maintained from day 17 (39.8\% of total follicles) to 19 $(35.1 \%)$ of the cycle by insulin injections beginning on day 15 , compared with a reduction from 41.7 to $16.6 \%$ in saline-treated animals. A corresponding increase in atretic follicles from 15.5 to $38.2 \%$ occurred in control animals, while a reduction in atretic follicles on both days $17(6.3 \%)$ and 19 $(10.7 \%)$ was observed in insulin-treated animals (Matamoros et al., 1991). This evidence is supported by the in vitro data presented in Fig. 3. Further evidence that the $5 \mathrm{~mm}$ follicle population is 

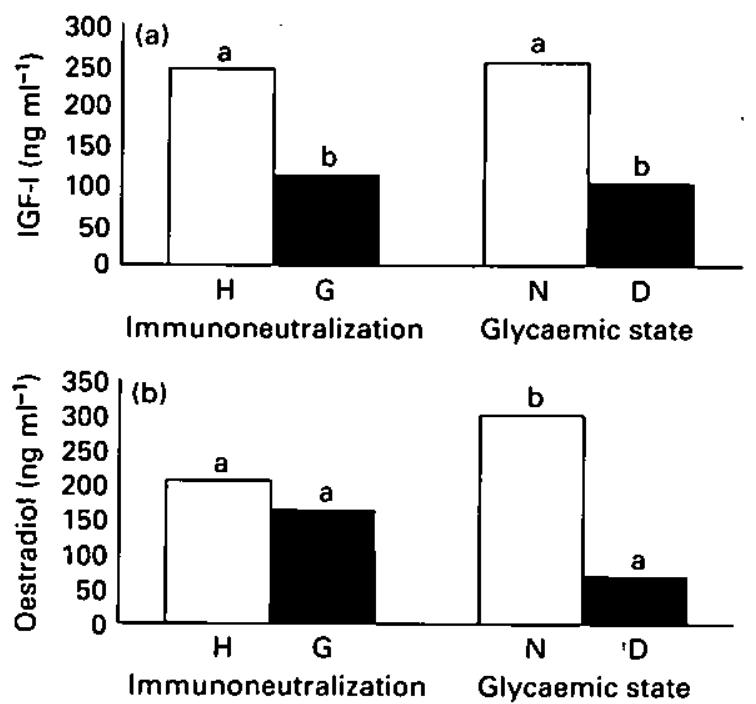

Fig. 4. Influence of immunoneutralization of GHRH on concentrations of (a) IGF-I and (b) oestradiol in the five largest follicles present on day 18 of the oestrous cycle in gilts $(n=22)$. The letters $\mathrm{H}$ and $\mathrm{G}$ designate gilts immunized against human serum albumin (HSA) and an HSA-GHRH conjugate, respectively, and the letters $\mathrm{N}$ and $D$ represent normal and streptozotocin-diabetic gilts, respectively. Insulin replacement therapy was removed from diabetic gilts on day 12 of the oestrous cycle. There were no interactions, and both main effects significantly reduced IGF-I, but only diabetes mellitus reduced oestradiol $(P<0.05)$. SEMs ranged from 15.3 to 25.0 and from 13.3 to 19.1 for ICF-I and oestradiol, respectively. Redrawn from Howell et al. (1993).

vulnerable to altered metabolic support was obtained by Edwards et al. (1996). In diabetic gilts, the largest follicles present on the ovary were $5 \mathrm{~mm}$ in diameter, and oestradiol production in vitro was similar to that of follicles from control and diabetic insulin-treated gilts. However, IGF-I was severely reduced in those follicles, indicating that either insulin, IGF-I or a combination thereof is necessary for follicle growth beyond the $5 \mathrm{~mm}$ stage. While research has demonstrated that insulin is required for normal follicle function; manipulating follicle development in gilts with insulin is not of practical use, because, as noted above, maximal ovulation rates can be obtained with feeding. Table 1 illustrates the lack of an effect of insulin on ovulation rates and litter size in gilts fed ad libitum, for which ovulation rates were maximal, and is in agreement with the observations of Beltranena $e t a l$. (1991) cited above. Insulin was not given to limit-fed gilts because of the danger of hypoglycaemia.

Effects on reproductive performance in primiparous sows. In sows after weaning, there is potential for manipulating reproduction with metabolic modifiers such as insulin, because ovulation occurs in the face of the recent negative energy balance of lactation. On the basis of initial studies with gilts, in several studies in commercial settings we have administered insulin during the period between weaning and oestrus and have observed inconsistent, but positive effects on reproductive function (Table 2). These effects include increasing farrowing rate in a herd with typically low farrowing rates and increasing litter size in another herd with greater than $90 \%$ farrowing rate (Ramirez et al., 1997). These results contrast with those of Kirkwood and Thacker (1991), who did not find a significant effect of exogenous insulin on litter size, using a higher daily dose of insulin $\left(0.75\right.$ versus $0.40 \mathrm{iu} \mathrm{kg}^{-1}$ day-1 $\left.^{-1}\right)$ 


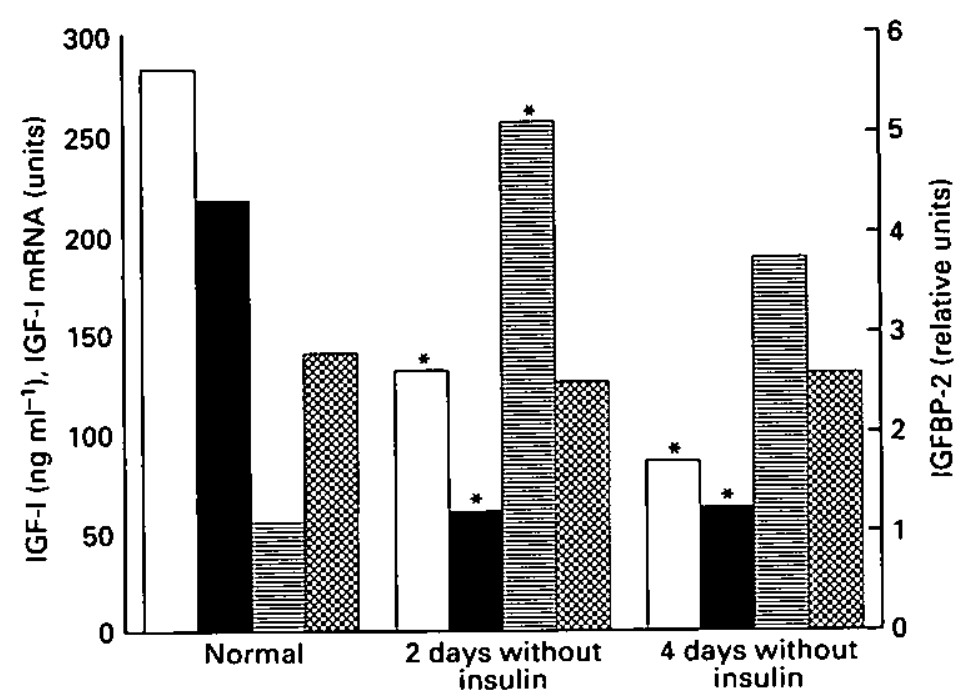

Fig. 5. Influence of removal of insulin therapy from diabetic gilts on ( $\square$ ) IGF-1 and (目) IGFBP-2 in follicular fluid and mRNA for ( $\square$ ) IGF-I and (因) IGFBP-2 in follicle walls. Insulin removal for 2 or 4 days decreased IGF-I and its mRNA and increased follicular fluid IGFBP-2 $(P<0.05)$ but did not affect its mRNA. SEMs ranged from 9.8 to 15.6 and 4.9 to 10.4 for IGF-I concentration and mRNA and from 0.3 to 0.5 and 0.9 to 1.5 for IGFBP-2 in follicular fluid and mRNA, respectively. Redrawn from Cox et al. (1995).

and mixed parity sows. Their results indicate that insulin did not influence ovulation rate, that uterine capacity was insufficient, or that mature sows already ovulated maximally. We also failed to increase litter size in multiparous sows treated with insulin (Cox et al., 1995). When primiparous and multiparous sows were compared, total litter size was not affected by insulin but was higher, as expected, for multiparous sows compared with primiparous sows (11.8 and 9.8 pigs born in total, SEM $=0.3 ; P<0.001)$. Farrowing rates $(89.7 \pm 3 \%$ overall) were not influenced by parity or insulin treatment.

In a study with primiparous sows lactating for 30 days, doses of insulin were higher and given for longer than in other studies (Table 2), and insulin treatment lowered ovulation rate (Rojkittikhun, 1992). This finding may be related to production of a negative metabolic signal by the increased duration of injection, the small sample sizes or to the fact that some of the treated sows gave birth to a smaller number of piglets in their previous litter, indicating a predetermined low ovulation rate.

Since increased feed intake alone between weaning and oestrus might be sufficient to increase insulin, we examined the influence of insulin injections daily for 4 days between weaning and postweaning oestrus in primiparous sows given extra feed between weaning and postweaning oestrus in a $2 \times 2$ arrangement (Cox et al., 1995). Total litter size in primiparous sows (in oestrus within 10 days after weaning) was affected differently by insulin depending on the level of feed intake between weaning and oestrus (treatment by feed level interaction, $p<0.02$ ) and was also positively related to feed intake during lactation $(P<0.05)$. When litter sizes, adjusted for lactation feed intake, were compared with the mean of insulin-treated sows given $3.63 \mathrm{~kg}$ feed (11.6 piglets in total), means for the insulin $/ 2.72 \mathrm{~kg}$ and saline $/ 3.63 \mathrm{~kg}$ treatments $(9.6$ piglets each) were lower $(P<$ $0.05)$ and the mean for the saline $/ 2.72 \mathrm{~kg}$ (10.5 piglets) treatment was similar $(P=0.10$; overall SEM $=$ $0.7)$. It should also be noted that despite the larger litter size in the insulin-treated sows fed $3.63 \mathrm{~kg}$, farrowing rate tended $(P<0.07)$ to be lower in this treatment group $(74 \pm 8 \%)$, compared with $86 \pm 5$, $89 \pm 5$, and $93 \pm 8 \%$ for saline $/ 2.72 \mathrm{~kg}$, insulin $/ 2.72 \mathrm{~kg}$ and saline $/ 3.63 \mathrm{~kg}$ treatment combinations, respectively. Although the greatest litter size was achieved with insulin plus the high level of feed, the tendency for lower farrowing rates suggests that there are negative effects of this combination of insulin and extra feed. The results show that primiparous sows may have a critical need to be in a 
Table 1. Effects of exogenous insulin and feed intake on ovulation rate and litter size in gilts

\begin{tabular}{lccc}
\hline Treatment & Number of gilts & Corpora lutea & $\begin{array}{c}\text { Number of fetuses at } \\
60 \text { days }\end{array}$ \\
\hline Limit-fed & 14 & $13.2^{\mathrm{b}}$ & Not mated \\
Ad libitum feed & 36 & 17.5 & 12.0 \\
Ad libitum + insulin once a day $\mathrm{c}$ & 37 & 17.2 & 11.4 \\
Ad libitum + insulin twice a day & 31 & 17.9 & 12.3 \\
SEM & & 0.9 & 0.5 \\
\hline
\end{tabular}

-A diet based on com and soybean meal (14\% protein) was limit-fed to provide 5400 kcal metabolizable energy (1.8 kg day-1) or fed ad libitum. Data from Ramirez, 1994.

-Significantly different from the other treatments $(P<0.05)$.

'Each insulin treatment provided a total of $0.80 \mathrm{IU} \mathrm{kg}^{-1}$ day' Lente insulin (Eli Lilly and Company, Indianapolis, $\mathbf{N}$ ).

certain metabolic condition for insulin to be effective. More appropriate feeding regimens may permit an augmented and repeatable reproductive response to insulin. More recently interval to oestrus was decreased but ovulation rate (18.3 average) and litter size (10.3) were unaffected by insulin (N. Whitley, unpublished observation, Table 2). Taken together, these results are consistent with the notion that insulin increased the anabolic state of sows, but the positive effects were manifested in different ways.

Manipulation of post-weaning follicle development in sows. In lactating sows, follicle growth advances as lactation advances, but follicles reach only about $5 \mathrm{~mm}$ in diameter by 3-4 weeks of lactation (Britt et al., 1985). Follicular growth patterns during lactation and after weaning measured ultrasonically illustrate that within 2 or 3 days after weaning, the 4-5 mm follicles are replaced by larger follicles (M. Lucy, personal communication). We have conducted one study in which follicle populations were monitored after insulin administration to primiparous sows for 3 or 5 days after weaning (Whitley et al., 1997a). Insulin increased atresia and the number of $6 \mathrm{~mm}$ follicles at 3 days after weaning and the overall number of follicles present at day 5, but at both 3 and 5 days after weaning follicular fluid IGF-I, IGFBP-2 and oestradiol were reduced. These results suggest that insulin may have increased numbers of follicles without increasing steroidogenesis by attenuating IGF-I. Perhaps the lowered IGFBP-2 allowed follicles to escape atresia. However, in another study, insulin increased oestradiol in medium- and large-sized follicles but did not affect IGF-I or IGFBP-2 (Whitley et al., 1997b). It is assumed that in the latter study insulin may not have lowered peripheral glucose concentrations as much (not measured), because animals received $0.45 \mathrm{~kg}$ more feed per day between weaning and oestrus, and the duration of lactation was 21 days, compared with 30 days in the former study. In addition to increasing oestradiol, insulin administration in the second study also resulted in increased follicular testosterone (not shown) and progesterone in a pattern similar to that for oestradiol.

The effects of insulin reported to date, while generally positive, are not consistent. However, the results are consistent with an overall anabolic effect that could variously affect follicles, oocytes or embryos, reproductive tract environment or gonadotrophin actions. Administration of insulin may provide a physiological signal of increased anabolism before the time such a state would normally occur after weaning, but coincident with preovulatory follicle growth.

\section{Pig somatotrophin}

Results of studies investigating the control of follicular development and ovulation rate after administration of pig somatotrophin (pST) are contradictory. Positive effects of pST have been 


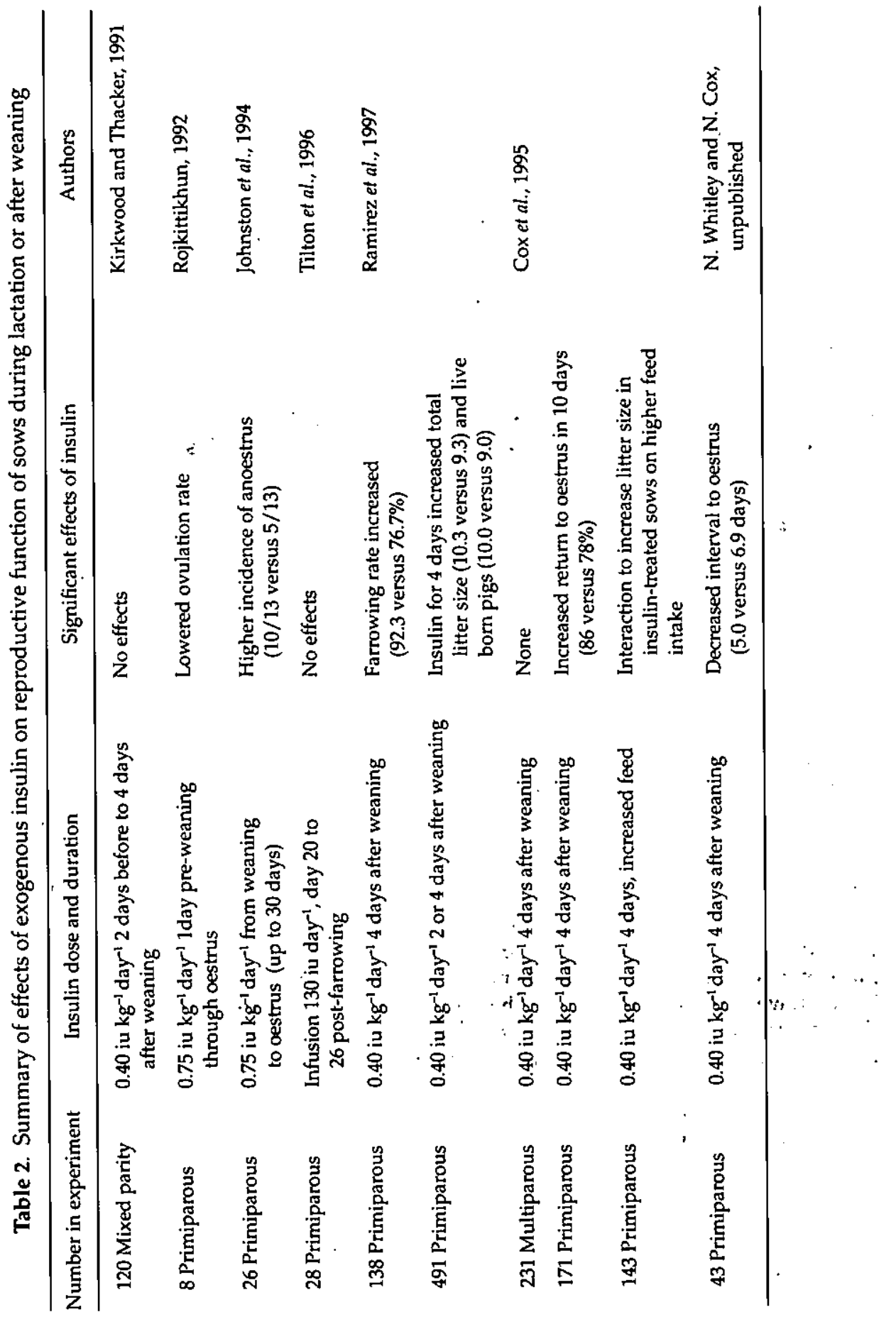


observed for IGF-I production in vitro by pig granulosa cells (Spicer and Echternkamp, 1995) as well as other species, and synergism of ST with gonadotrophins has been demonstrated in humans undergoing superovulation (Homburg et al., 1988). In early antral rat follicles in culture, rbST increased IGF-I messenger RNA but did not reduce apoptosis (Chun et al., 1996).

Many attempts in vivo to increase follicular development involved administration of pST during follicular development (Table 3). Administration during the prepubertal period has had few permanent effects on reproductive characteristics, with the exception of the study of Echternkamp et al. (1994), who used low doses of pST in sustained release implants. Treatment with $4 \mathrm{mg}^{\mathrm{pST}}$ day ${ }^{-1}$ interacted with body type to increase the number of medium-sized follicles, with a greater initial number in control compared with lean and obese body types (12,2 and 4, respectively) and 23,9 and 11 follicles in control, lean and obese gilts treated with $4 \mathrm{mg} \mathrm{PST} \mathrm{day}^{-1}$. Importantly, PST decreased IGFBP-2 concentration in follicular fluid but not in serum.

In cyclic animals, pST can have potent effects on the occurrence of oestrus. Kirkwood et al. (1988) administered pituitary-derived pST from day 14 of the oestrous cycle to $24 \mathrm{~h}$ after oestrus. This dose increased insulin and glucose concentrations on day 20 of the oestrous cycle, and ovulation rate was increased by pST (12.4 for control and 14.3 for pST-treated). However, nine of 20 pST-treated gilts were anoestrous, whereas none of the control animals were anoestrous. The anoestrous gilts tended to have lower insulin and glucose values, which may have been beneath a threshold necessary for continued cycling. Despite ad libitum feeding, pigs did not gain weight during the experimental period, adding additional credence to the idea that there is a critical threshold of metabolism below which metabolic modifiers can have harmful peripheral effects. A critical period for inhibition of oestrus with pST was determined by Kirkwood et al. (1989). They observed that administration of pST beginning on day 14, but not day 17, suppressed the subsequent oestrus, illustrating that pST may affect follicles negatively during follicle selection. In a follow-up experiment, treatment was shortened to days 14-17 of the oestrous cycle, and that treatment resulted in an increase in percentage in oestrus $(91 \%)$ compared with gilts treated from day 14 to day $22(73 \%)$, but no increase in ovulation rate. It should be noted that the ovulation rate of the controls in this experiment was 14.0, compared to 12.3 in the study of Kirkwood et al. (1988). Thus ovulation rate must be below a physiological maximum in order to be increased by metabolic modifiers, which may explain the inconsistent results for the two studies.

Preovulatory development in sows may also be manipulated by pST, although farrowing rate and litter size in multiparous sows were not affected by treatment with $6 \mathrm{mg} \mathrm{pST}$ day $^{-1}$ from 2 days before weaning to 4 days after weaning (Kirkwood et al., 1993). Recently we treated primiparous sows with $40 \mu \mathrm{g} \mathrm{pST} \mathrm{kg}^{-1} \mathrm{day}^{-1}$ (dose of approximately $6 \mathrm{mg}^{-1 a y}{ }^{-1}$ ) beginning one day after weaning and observed increased IGF-I on day 5 (Whitley et al., 1997b). The only IGFBPs increased by pST treatment in this model were the 30 and $22 \mathrm{kDa}$ species, but the relevance of this increase is questionable since these IGFBPs are present in small quantities and proteolysis of these IGFBPs is related to follicle development (Besnard et al., 1997). Follicular fluid oestradiol and testosterone were also increased by PST and insulin, indicating that ST may have positive effects on follicular development in sows if administered during the 5 days after weaning. In summarizing the potential applicability of manipulation with ST, increased follicular development is possible with appropriate dosages and administration, but the influence on pregnancy establishment has not been evaluated.

\section{Conclusion}

Parallel with information on the intrafollicular control of ovarian function, progress has been made in the practical application of metabolic modification of reproductive function. Metabolic manipulation of follicles is most successful in follicles of intermediate development, which have the potential for atresia or ovulation, depending on metabolic and gonadotrophin support. Progress in control of follicular development and ovulation rate will depend on a better understanding of these factors as well as the influence of metabolic state when metabolic hormones are administered. It can be concluded that metabolic modifiers may be harmful if body condition is below average and may 


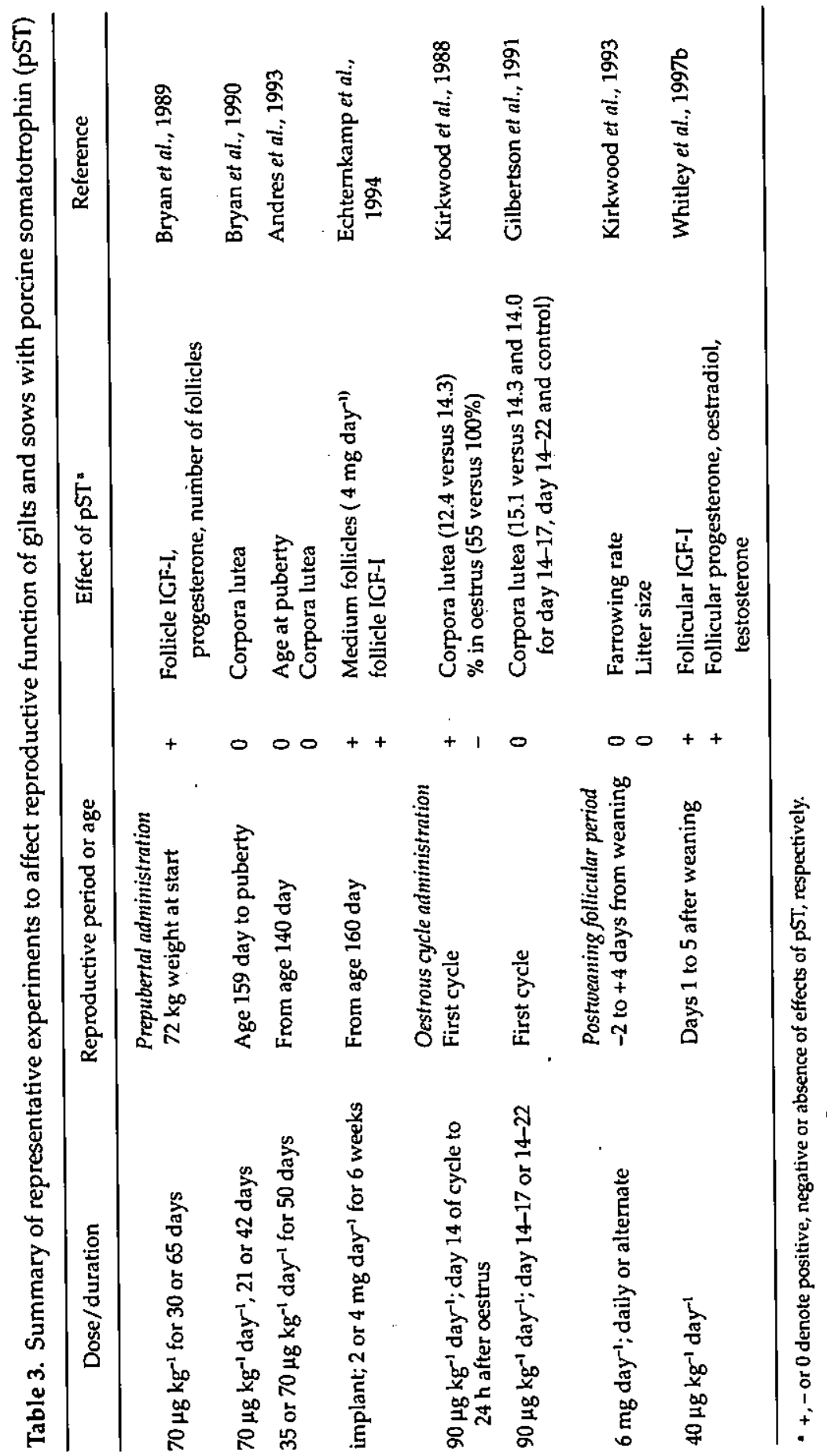


be unnecessary if body condition is above average. Enhancing ovulation rate by manipulating the preovulatory follicle is possible in gilts and appears to be possible in sows, although less reliable. Gilts can be managed such that ovulation rate is not limiting to litter size. However, follicle development in sows may benefit from anabolic signals applied for a short enough time to enhance reproduction without causing deleterious peripheral metabolic effects. Thus it is more practical to consider application of metabolic modifiers to produce anabolic signals during preovulatory follicle growth in sows. Future progress in this area will involve assessing effects of metabolic manipulation on embryo quality, as well as integration of research on intrafollicular factors which control fertility.

The author gratefully acknowledges the excellent assistance in interpretation of data and preparation of the manuscript provided by A. B. Moore, J. Purvis, B. F. Stevens, N. C. Whitley and H. Zhang and the data generously contributed by H.D. Guthrie, W. M. Garrett and M. C. Lucy.

\section{References}

Andres CJ, Green ML, Clapper JA, Cline TR, Diekman MA and Thomford PJ (1993) Influence of porcine somatotropin on endocrine and histological variables in gilts fournal of Animal Science 71 1552-1560

Angell CA, Tubbs RC, Moore AB, Barb CR and Cox NM (1996) Depressed luteinizing hormone response to estradiol in vivo and gonadotropin-releasing hormone in vitro in experimentally diabetic swine Domestic Animal Endocrinology $13453-463$

Beltranena E, Aherne FX, Foxcroft, GR and Kirkwood RN (1991) Effects of pre- and post-pubertal feeding on production traits at first and second estrus in gilts Journal of Animal Science 69 886-893

Besnard N, Pisselet C, Monniaux D and Monget P (1997) Proteolytic activity degrading insulin-like growth factor-binding protein-2,-3,-4, and -5 in healthy growing and atretic follicles in the pig ovary Biology of Reproduction 56 1050-1058

Booth PJ (1990) Metabolic influences on hypothalamicpituitary-ovarian function in the pig joumal of Reproduction and Fertility Supplement 40 89-100

Britt JH, Armstrong JD, Cox NM and Esbenshade KL, (1985) Control of follicular development during and after lactation in sows Journal of Reproduction and Fertility Stupplement 33 37-54

Britt JH, Armstrong JD and Cox NM (1988) Metabolic interfaces between nutrition and reproduction in pigs Proceedings of the 11th International Congress on Animal Reproduction and Artificial Insemination 5 117-125

Bryan KA, Hammond JM, Canning S, Mondschein J, Carbaugh DE, Clark AM and Hagen DR (1989) Reproductive and growth responses of gilts to exogenous porcine pituitary growth hormone Joumal of Animal Science 67 196-205

Bryan KA, Clark AM and Hagen DR (1990) Effect of treatment with and subsequent withdrawal of exogenous porcine somatotropin on growth and reproductive characteristics of gilts Journal of Animal Science 68 2357-2361

Cardenas H and Pope WF (1997) Administration of testosterone on day 13 of the estrous cycle to estrus increased the number of corpora lutea and conceptus survival in gilts Journal of Animal Science 75 202-207

Chartton ST, Cosgrove JR, Glimm DR, and Foxcroft GR (1993) Ovarian and hepatic insulin-like growth factor-I gene expression and associated metabolic responses in prepubertal gilts subjected to feed restriction and refeeding Journal of Endocrinology 139 143-152
Chun S, Billig H, Tilly JL, Furuta I, Tsafriri A and Hsueh AJW (1994) Gonadotropin suppression of apoptosis in cultured preovulatory follicles: mediatory role of endogenous insulin-like growth factor I Endocrinology 135 1845-1853

Chun S, Eisenhauer KM, Minami S, Billig H, Perlas E and Hsueh AJW (1996) Hormonal regulation of apoptosis in early antral follicles: follicle-stimulating hormone as a major survival factor Endocrinology 137 1447-1456

Clowes EJ, Aheme FX and Foxcroft GR (1994) Effect of delayed breeding on the endocrinology and fecundity of sows Journal of Animal Science 72 283-291

Cosgrove JR and Foxcroft GR (1996) Nutrition and reproduction in the pig: ovarian aetiology Animal Reproduction Science 42 131-141

Cox NM, Stuart MJ, Althen TG, Bennet WA and Miller HW (1987) Enhancement of ovulation rate in gilts by increasing dietary energy and administering insulin during follicular growth Journal of Animal Science 64 507-516

Cox NM, Meurer KA, Carlton CA, Tubbs RC and Mannis DP (1994) Diabetes during the luteal phase of the estrous cycle affects preovulatory follicular function and prevents ovulation but does not impair gonadotropins journal of Reproduction and Fertility $10177-86$

Cox NM and Qiu Y (1995) Effect of duration of insulin withdrawal on apoptosis and estradiol in preovulatory follicles of swine with insulin-dependent diabetes mellitus Joumal of Animal Science 73 (Supplement 1) 218

Cox NM, Quirk MN, Moore AB and Ramirez JL (1995) Influences of parity and level of food intake on reproductive responses to insulin administered to sows after weaning Journal of Animal Science 73 (Supplement 1) 218

Echternkamp SE, Spicer LJ, Klindt J, Vemon RK, Yen JT and Buonomo FC (1994) Administration of porcine somatotropin by a sustained-release implant: effect on follicular growth, concentrations of steroids and insulin-like growth factor 1 , and insulin-like growth factor binding protein activity in follicular fluid of control, lean, and obese gilts journal of Animal Science 72 2431-2440

Edwards JL, Hughey TC, Moore AB and Cox NM (1996) Depletion of insulin in streptozocin diabetic pigs alters estradiol, IGF-I and its binding proteins in cultured ovarian follicles Biology of Reproduction 55 775-781 
Einarsson $S$ and Rojkittikhun (1993) Effects of nutrition on pregnant and lactating sows Joumal of Reproduction and Fertility 48 229-239

Findlay JK, Drummond AE and Fry RC (1996) Intragonadal regulation of follicular development and ovulation Animal Reproduction Science 42 321-331

Flowers B, Martin MJ, Cantley TC and Day BN (1989) The effect of pregnant mare serum gonadotropin on follicle stimulating hormone and estradiol secretion in the prepuberal gilt Animal Reproduction Science 21 93-100

Flowers WL and Tumer ZA (1996) In vitro growth of preantral follicles isolated from prepuberal gilts Joumal of Animal Science 74 (Supplement 1) 220

Foxcroft GR, Shaw HJ, Hunter MG, Booth PJ and Lancaster RT (1987) Relationships between luteinizing hormone, follicle-stimulating hormone and prolactin secretion and ovarian follicular development in the weaned sow Biology of Reproduction 36 175-191

Fricke PM, Ford J], Reynolds LP and Redmer DA (1996) Growth and cellular proliferation of antral follicles throughout the follicular phase of the estrous cycle in Meishan gilts Biology of Reproduction 54 879-887

Garrett WM and Guthrie HD (1996) Expression of androgen receptors and steroidogenic enzymes in relation to follicular growth and atresia following ovulation in pigs Biology of Reproduction 55 949-955

Gilbertson J, Kirkwood RN and Thacker PA (1991) Timing of growth hormone injections and reproduction in gilts Canadian Journal of Animal Science 71 717-723

Guthrie HD and Cooper BS (1996) Follicular atresia, follicular fluid hormones, and circulating hormones during the midluteal phase of the estrous cycle in pigs Biology of Reproduction 55 543-547

Guthrie HD, Bolt DJ and Cooper BS (1993) Changes in follicular estradiol-17 $\beta$, progesterone and inhibin immunoactivity in healthy and atretic follicles during preovulatory maturation in the pig Domestic Animal Endocrinology 10 $127-140$

Guthrie HD, Welch GR, Cooper BS, Zakaria AD and Johnson LA (1994) Flow cytometric determination of degraded deoxyribonucleic acid in granulosa cells to identify atretic follicles during preovulatory maturation in the pig Biology of Reproduction 50 1303-1311

Guthrie HD, Grimes RW, Cooper BS and Hammond JM (1995a) Follicular atresia in pigs: measurement and physiology Joumal of Animal Science 73 2834-2844

Guthrie HD, Grimes RW and Hammond JM (1995b) Changes in insulin-like growth factor-binding protein-2 and -3 in follicular fluid during atresia of follicles grown after ovulation in pigs Journal of Reproduction and Fertility 104 225-230

Hammond JM, Samaras SE, Grimes R, Leighton J, Barber J, Canning SF and Guthrie HD (1993) The role of insulin-like growth factors and epidermal growth factor-related peptides in intraovarian regulation in the pig ovary Journal of Reproduction and Fertility Supplement 48 117-125

Hombung R, Eshel A, Abdalla $\mathrm{Hl}$ and Jacobs HS (1988) Growth hormone facilitates ovulation induction by gonadotropins Clinical Endocrinology 29 113-117

Howard HJ and Ford JJ (1992) Relationships among concentrations of steroids, inhibin, insulin-like growth factor-1 (IGF-1), and IGF-binding proteins during follicular development in weaned sows Biology of Reproduction 47 193-201
Howell JL, Hughey TB, Cox NM, Lehman FD, Armstrong JD, Campbell RM and Heimer EP (1993) Effects of the absence of insulin and immunoneutralization of growth hormone releasing factor (GRF) on intrafollicular hormones in preovulatory follicles Journal of Animal Science 71 (Supplement 1) 217

Hsueh AJW, Billig $\mathrm{H}$ and Tsafriri A (1994) Ovarian follicle atresia: a hormonally controlled apoptotic process Endocrine Reviews 15 707-724

Hughey TB, Howell JL, Lehman FD, Cox NM and Moore AB (1993) Effects of exogenous insulin on intrafollicular hormones of preovulatory follicles during the estrous cycle Journal of Animal Science 71 (Supplement 1) 218

Johnston L], Pettigrew JE, Wilson ME, Walker RD and Crooker BA (1994) Influence of dietary molasses on reproductive performance of lactating sows journal of Animal Science 72 Supplement 1334

Kemp B, Soede NM, Helmond FA and Bosch MW (1995) Effects of energy source in the diet on reproductive hormones and insulin during lactation and subsequent estrus in multiparous sows Journal of Animal Science 73 3022-3029

King BF, Britt JH, Esbenshade KL, Flowers WL, Sesti LAC, Martin TL and Ireland JJ (1993) Ovulatory and endocrine responses after active immunization of gilts against a synthetic fragment of bovine inhibin Journal of Animal Science 71 975-982

King BF, Britt JH, Esbenshade KL, Flowers WL and Ireland JJ (1995) Evidence for a local role of inhibin or inhibin a subunits in compensatory ovarian hypertrophy foumal of Reproduction and Fertility 104 291-295

Kirkwood RN and Thacker PA (1991) The influence of premating feeding level and exogenous insulin on the reproductive performance of sows Canadian joumal of Animal Science 71 249-251

Kirkwood RN, Thacker PA, Gooneratne AD, Guedo BL and Laarveld B (1988) The influence of exogenous growth hormone on ovulation rate in gilts Conadian Journal of Animal Science 68 1097-1103

Kirkwood RN, Thacker PA, Guedo BL and Laarveld B (1989) The effect of exogenous growth hormone on the endocrine status and the occurrence of estrus in gilts Canadian joumal of Animal Science $69931-937$

Kirkwood RN, Peacock A] and Thacker PA (1993) The influence of growth hormone injections either pre- or post-breeding on the reproductive performance of sows and gilts Canadian Journal of Anintal Science 73 259-265

Koketsu Y, Dial GD, Pettigrew JE, Marsh WE and King VL (1996) Influence of imposed feed intake patterns during lactation on reproductive performance and on circulating concentrations of glucose, insulin, and luteinizing hormone in primiparous sows Journal of Animal Science 74 1036-1046

Matamoros 1A, Cox NM and Moore AB (1990) Exogenous insulin and additional dietary energy affect follicular distribution, follicular steroid concentrations and granulosa cell human chorionic gonadotropin binding in swine Biology of Reproduction 43 1-7

Matamoros IA, Moore AB and Cox NM (1991) Effects of exogenous insulin and body condition on metabolic hormones and gonadotropin-induced follicular development in prepuberal gilts Journal of Animal Science 69 2081-2091

McKinnie MR, Britt JH and Esbenshade KI. (1988) Ovarian function and hormone secretion of gilts actively immunized against androstenedione Joumal of Animal Science 66 3131-3143 
Meurer KA, Cox NM, Matamoros IA and Tubbs RC (1991) Decreased follicular steroids and insulin-like growth factor-I and increased atresia in diabetic gilts during follicular growth stimulated with PMSG journal of Reproduction and Fertility 91 187-196

Purvis J, Skelton JO, Quirk MN, Moore AB, Whitley NC and Cox NM (1997) Influence of insulin and insulin-like growth factor-I (IGF-I) on the function of porcine ovarian follicles in culture Journal of Animal Science 75 (Supplement 1) 1

Ramirez JL (1994) Use of Exogenous Insulin to Influence Fertility in Swine PhD Dissertation. Mississippi State University

Ramirez JL, Moore AB and Cox NM (1997) Influence of insulin administration to primiparous sows after weaning on subsequent reproductive performance Journal of Animal Science (in press)

Rojkittikhun $\mathbf{T}$ (1992) Clinical and Endocrinological Studies in Lactating and Post-Weaning Primiparous Sows PhD Dissertation. Swedish University of Agricultural Science, Uppsala

Spicer LJ and Echtemkamp SE (1995) The ovarian insulin and insulin-like growth factor system with an emphasis on domestic animals Domestic Animal Endocrinology 12 223-245

Tilton JE, Plaine KJ, Weigel RM and Swantek PM (1996) Insulinlike growth factor and luteinizing hormone concentrations in the insulin treated weaned sow Proceedings of the 13th International Congress on Animal Reproduction $316-6$

Tokach MD, Pettigrew JE, Dial GD, Wheaton JE, Crooker BA and Johnston LJ (1992a) Characterization of luteinizing hormone secretion in primiparous lactating sows: relationship to blood metabolites and return-to-estrus interval Joumal of Animal Science 70 2195-2201

Tokach MD, Pettigrew JE, Dial GD, Wheaton JE, Crooker BA and Koketsu Y (1992b) influence of glucose infusions on luteinizing hormone secretion in the energy-restricted, primiparous, lactating sow Journal of Animal Science 70 2202-2206

Tonetta SA and diZerega GS (1990) Local regulatory factors controlling folliculogenesis in pigs Journal of Reproduction and Fertility Supplement 40 151-161

Vesseur PC, Kemp B and den Hartog LA (1994) The effect of the weaning to estrus interval on litter size, live born piglets and farrowing rate in sows fournal of Animal Physiology and Animal Nutrition 71 30-38

Whitley NC, Quirk MN, Skelton JO, Moore AB, Purvis J, Qiu Y and Cox NM (1997a) Influence of insulin on follicular development and the intrafollicular IGF-I system in sows Journal of Reproduction and Fertility (in press)

Whitley NC, Moore AB and Cox NM (1997b) Comparative effects of insulin and porcine somatotropin (PST) on postweaning follicular development in sows Jourmal of Animal Science (in press)

Wu MC, Hentzel MD and Dziuk PJ (1987) Relationships between uterine length and number of fetuses and prenatal mortality in pigs Journal of Animal Science 65 762-770

Yuan W, Lucy MC and Smith MF (1996) Messenger ribonucleic acid for insulin-like growth factors-I and -II, insulin-like growth factor binding protein-2, gonadotropin receptors, and steroidogenic enzymes in porcine follicles Biology of Reproduction 55 1045-1054

Zak LJ, Cosgrove JR, Aheme FX and Foxcroft GR (1997) Pattern of feed intake and associated metabolic and endocrine changes differentially affect postweaning fertility in primiparous lactating sows Jourual of Animal Science 75 208-216

Zhou J, Adesanya OO, Vatzias G, Hammond JM and Bondy CA (1996) Selective expression of insulin-like growth factor system components during porcine ovary follicular selection Endocrinology $1374893-4901$ 